\title{
Chemical Composition and Antimicrobial Activity of Essential Oil from Justicia schimperiana
}

Wondwosen Abebe ${ }^{1,2}$, Wanchang Zhang ${ }^{1}$, Shuo Zhang ${ }^{1}$ and Guangbo Xie ${ }^{1^{*}}$

${ }^{1}$ School of Life Science and Technology, University of Electronic Science and Technology of China, Chengdu, China

${ }^{2}$ Department of Chemical Engineering, Hawassa University Institute of Technology, Hawassa, Ethiopia

"Corresponding author: Xie G, School of Life Science and Technology, University of Electronic Science and Technology of China, Chengdu, China, Tel: +8613882096798; E-mail: gbxie@uestc.edu.cn

Received date: May 02, 2018; Accepted date: May 14, 2018; Published date: May 17, 2018

Copyright: (๑) 2018 Abebe W, et al. This is an open-access article distributed under the terms of the Creative Commons Attribution License, which permits unrestricted use, distribution and reproduction in any medium, provided the original author and source are credited.

Abstract
Background:
Justicia schimperiana is popularly used as folk medicines in Ethiopia.
Objective:
The chemical composition of essential oils from the leaves of Justicia schimperiana was analyzed and its
antimicrobial activities were evaluated.
Methods:
The essential oil was obtained by steam distillation and its chemical constituents were separated and identified
by GC-MS, using normalization method to calculated relative amount. Its antimicrobial activities were evaluated
by micro dilution method against Escherichia coli, Bacillus subtilis and Candida albicans.
Results:
From the essential oil of Justicia schimperiana, 28 compounds were identified; making up $75.18 \%$, the essential
oil of Justicia schimperiana has not showed obvious activity against Escherichia coli, Bacillus subtilis and Candida
albicans.
Conclusion:
This is the first report on the chemical compositions and antimicrobial activities of essential oils obtained from
Ethiopian Justicia schimperiana.

Keywords: Justicia schimperiana; Essential oil; Antimicrobial activity

\section{Introduction}

Traditional medicine has been practiced in virtually all cultures and it has expanded globally and is gaining popularity [1]. In Ethiopia, the knowledge of traditional medicine has been transferred from one generation to another and about $80 \%$ of the Ethiopian population is still dependent on traditional medicine, especially the usage of plants $[2,3]$.

Justicia schimperiana (Hochst. ex Nees), belongs to the family Acanthaceae and it is a shrub with branched stems [4]. In Ethiopia, $J$. schimperiana was used for the treatment of stomach complaints, malaria, hepatitis, asthma, jaundice, epilepsy, etc [5]. Essential oils are complex mixtures of volatile substances generally present at low concentrations and they are important components used for their flavor and fragrances in food, pharmaceutical and perfumery industries [6]. Although there are some reports on the pharmacology of $J$. schimperiana mentioned above, but no research on essential oil has been performed [2,5,7]. Here we will focus on the chemical composition and antimicrobial properties of essential oils from this medicinal plant.

\section{Methods and Methods}

\section{Plant material}

The leaves of $J$. schimperiana, was collected in October 2015, from Addis Zemen, which is a town in Northern-Central Ethiopia, Located in the Debub Gondar Zone of the Amhara Region, on the road connecting Gondar and Bahir Dar. The plant was identified by Amare Seifu Assefa, a botanist from Ethiopian Biodiversity Institute.

\section{Extraction of essential oil}

The leaves of J. schimperiana (200 g) were coarsely powdered and transferred into a flask with $1.5 \mathrm{~L}$ water. Then it was submitted to 
Page 2 of 3

steam distillation process, in a Clevenger's apparatus for $8 \mathrm{~h}$. The distillates were saturated with $\mathrm{NaCl}$ and extracted with diethyl ether. The organic phase was dried by anhydrous $\mathrm{Na}_{2} \mathrm{SO}_{4}$ and then recycled the organic solvent at $30^{\circ} \mathrm{C}$ to give the essential oil. The essential oil was stored at $4^{\circ} \mathrm{C}$ in refrigerator for further use.

\section{Analysis of essential oil}

The GC-MS analyses of the essential oil was carried out using an Agilent 6890 gas chromatograph interfaced with an Agilent 5973N mass spectrometer fitted with a HP-5MS capillary column $(30 \mathrm{~m} \times$ $0.25 \mathrm{~mm}, 0.25 \mu \mathrm{m}$ film thickness). Gas chromatography condition: the temperature programmed at $70^{\circ} \mathrm{C}$ for the first two minutes, increased at a rate of $5^{\circ} \mathrm{C} /$ minute to $300^{\circ} \mathrm{C}$ and held isothermal at $300^{\circ} \mathrm{C}$ for the next 2 minutes; The injector temperature was $250^{\circ} \mathrm{C}$; The injected volume was $1 \mu \mathrm{L}$; Helium was used as carrier gas; Flow rate was 1 $\mathrm{mL} / \mathrm{min}$ with a split ratio of $1: 20$; Mass spectrometry condition: EI ionization mode, $70 \mathrm{eV}$, scan range 30-500 Amu, ion source temperature was $230^{\circ} \mathrm{C}$. Individual components were identified by matching their mass spectra with those of the spectrometer data base (NIST 11). For quantification purposes, relative area percentages were used without the use of correction factors.

\section{Antimicrobial activities}

Escherichia coli (ATCC 25922), Bacillus subtilis (ATCC 6633) and Candida albicans (ATCC 60193) were used for antimicrobial evaluation. Antimicrobial activity assays were performed in 96-well sterilized microplates using a microdilution method described previously $[8,9]$. The 18 -h-old bacterial cultures from E. coli, B. subtilis were added to $\mathrm{LB}$ broth medium ( $1 \mathrm{~L}$ water, $10 \mathrm{~g}$ tryptone, $5 \mathrm{~g}$ yeast extract and $10 \mathrm{~g} \mathrm{NaCl})$ to reach $1 \times 10^{5} \mathrm{CFU} / \mathrm{ml}$ and the 4-day-old spores from $C$. albicans were added to PDB medium (potato $20 \%$, glucose $2 \%$ ) to research $1 \times 10^{3}$ spores $/ \mathrm{mL}$. The test samples were dissolved in DMSO and their final concentrations were ranged from 0.5 to $512 \mu \mathrm{g} / \mathrm{mL}$, which were determined by 2 -fold serial dilution method. The wells containing test strains and diluted samples were incubated at $37^{\circ} \mathrm{C}\left(24 \mathrm{~h}\right.$ ) for bacteria and $28^{\circ} \mathrm{C}$ (4 days) for fungi. The wells containing a culture suspension and DMSO were run as negative controls. Kanamycin (for bacteria) and nystatin (for fungi) were introduced as positive controls. All experiments were repeated twice. The Minimal Inhibitory Concentration (MIC) was defined as the lowest antibiotic concentration that produced complete growth inhibition of the tested microorganisms.

\section{Results and Discussion}

Steam distillation of the leaves of $J$. schimperiana, gave dark brown oil (yield $0.016 \% \mathrm{w} / \mathrm{w}$ ). The chemical constituents of the essential oil, along with its retention time and relative percentages, were given in Figure 1 and Table 1.

A total of twenty eight components were identified from J. Schimperiana essential oil, representing $75.18 \%$ of the total oil. Eucalyptol (24.13\%), espatulenol (7.25\%), crypton (5.08\%) and 1octen-3-ol (5.06\%) were the main constituents. The oil sample was found to be rich in monoterpenoids, including eight compounds, which representing $53.91 \%$ of the total identified components.

The essential oil obtained from leaves of $J$. schimperiana, was tested for its antimicrobial activity against E. coli (Gram-negative), B. subtilis (Gram-positive) and $C$. albicans (fungi). The results (Table 2) indicated that no obvious antimicrobial activity has been observed.

\begin{tabular}{|c|c|c|}
\hline Components & Retention time (min) & Area \\
\hline 1-Octen-3-ol & 4.67 & $5.06 \%$ \\
\hline o-Cymene & 5.65 & $0.74 \%$ \\
\hline Eucalyptol & 5.79 & $24.13 \%$ \\
\hline beta-Terpineol & 6.62 & $0.40 \%$ \\
\hline Epoxylinalool & 6.75 & $2.59 \%$ \\
\hline Linalool & 7.40 & $1.45 \%$ \\
\hline $\begin{array}{l}\text { trans-1-Methyl-4-(1-methylethyl)-2- } \\
\text { cyclohexen-1-ol }\end{array}$ & 7.96 & $0.81 \%$ \\
\hline (-)-Terpinen-4-ol & 9.39 & $4.77 \%$ \\
\hline Crypton & 9.63 & $5.08 \%$ \\
\hline 2-Methyl-3-phenylpropanal & 11.12 & $2.04 \%$ \\
\hline 4-isopropylbenzyl alcohol & 12.59 & $1.30 \%$ \\
\hline Durenol & 12.92 & $1.07 \%$ \\
\hline alpha-Terpinyl acetate & 13.85 & $4.48 \%$ \\
\hline Eugenol & 14.32 & $0.33 \%$ \\
\hline Caryophyllene & 15.63 & $0.28 \%$ \\
\hline alpha-Ionone & 15.85 & $1.12 \%$ \\
\hline beta-Humulene & 16.64 & $0.45 \%$ \\
\hline beta-Ionone & 17.29 & $1.94 \%$ \\
\hline Dihydroactindiolide & 18.37 & $2.79 \%$ \\
\hline Espatulenol & 19.45 & $7.25 \%$ \\
\hline Caryophyllene oxide & 19.57 & $1.53 \%$ \\
\hline beta-Eudesmol & 21.12 & $0.67 \%$ \\
\hline 6,10,14-Trimethylpentadecan-2-one & 25.21 & $1.83 \%$ \\
\hline Phytol & 30.35 & $1.38 \%$ \\
\hline Tritetracontane & 36.73 & $0.47 \%$ \\
\hline 11-Decyl-tetracosane & 38.25 & $0.29 \%$ \\
\hline Heptacosane & 39.71 & $0.41 \%$ \\
\hline Octadecane & 42.48 & $0.52 \%$ \\
\hline
\end{tabular}

Table 1: Chemical components (\%) of the essential oils from Justicia schimperiana.

\begin{tabular}{|l|l|l|l|}
\hline Essential oil & $\begin{array}{l}\text { Escherichia } \\
\text { coli }\end{array}$ & $\begin{array}{l}\text { Bacillus } \\
\text { subtilis }\end{array}$ & $\begin{array}{l}\text { Candida } \\
\text { albicans }\end{array}$ \\
\hline Justicia schimperiana & $>128$ & $>128$ & $>128$ \\
\hline Kanamycin & 4 & 4 & - \\
\hline Nystatin & - & - & 4 \\
\hline
\end{tabular}

Table 2: Antimicrobial activities of the essential oils from Justicia schimperiana (MIC: $\mu \mathrm{g} / \mathrm{ml}$ ). 
Citation: Abebe W, Zhang W, Zhang S, Xie G (2018) Chemical Composition and Antimicrobial Activity of Essential Oil from Justicia schimperiana! J Pharmacogn Nat Prod 4: 154. doi:10.4172/2472-0992.1000154

Page 3 of 3

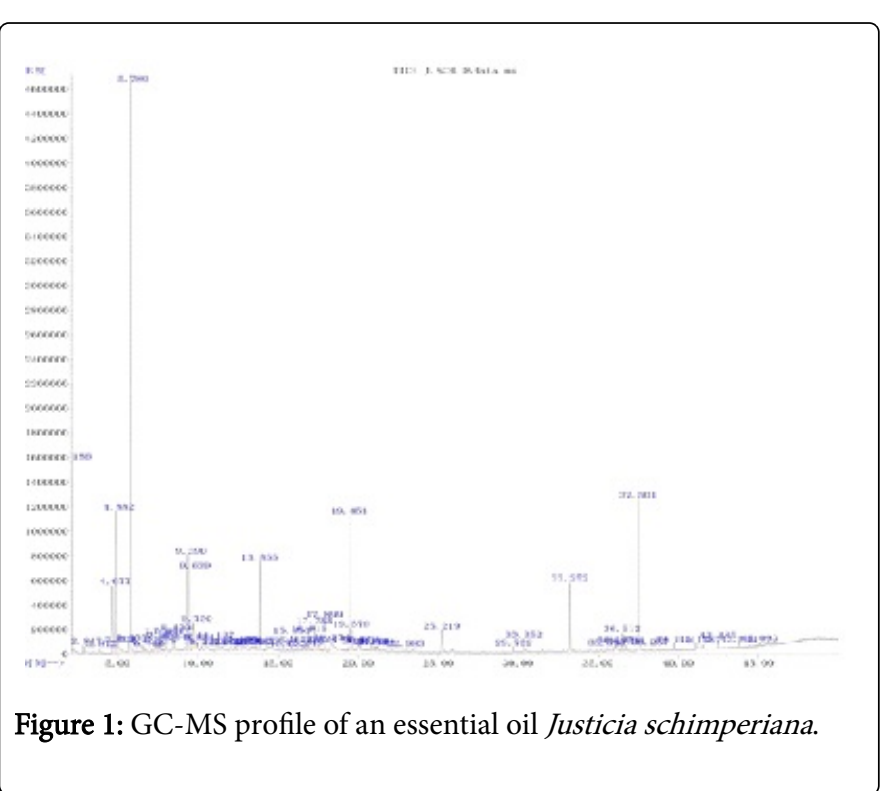

\section{Conclusion}

This is the first report on the essential oil of J. schimperiana, which is an important medicinal plant in Ethiopia. Terpenoids were found to be the major components in the GC-MS analysis of the essential oils. No distinct antimicrobial activities were found for this medicinal plant essential oil and further studies are required on the chemical composition and their bioactivities of this plant.

\section{Acknowledgement}

This work was financial supported by the Fundamental Research Funds for the Central University (ZYGX2016J120).

\section{References}

1. Galen E (2014) Traditional herbal medicines worldwide, from reappraisal to assessment in Europe. J Ethnopharmacol 158: 498-502.

2. Giday M, Teklehaymanot T, Animut A, Mekonnen Y (2007) Medicinal plants of the Shinasha, Agew-awi and Amhara peoples in Northwest Ethiopia. J Ethnopharmacol 110: 516-525.

3. Kassaye K, Amberbir A, Getachew B, Mussema Y (2006) A historical overview of traditional medicine practices and policy in Ethiopia. Ethiop J Health Dev 20: 127-134.

4. Hedberg I, Kelbessa E, Edwards S, Demissew S, Persson E, et al. (2006) Flora of Ethiopia and Eritrea. Addis Ababa: The National Herbarium of Addis Ababa University 5: 468.

5. Umer S, Asres K, Veeresham C (2010) Hepatoprotective activities of two Ethiopian medicinal plants. Pharm Biol 48: 461-468.

6. Maffei ME, Gertsch J, Appendino G (2011) Plant volatiles: Production, function and pharmacology. Nat Prod Rep 28: 1359-1380.

7. Abdela J, Engidawork E, Shibeshi W (2014) In vivo antimalarial activity of solvent fractions of the leaves of Justicia schimperiana Hochst. Ex Nees against Plasmodium berghei in mice. Ethiop Pharm J 30: 95-108.

8. Zhou H, Zhao L, Li W, Yang Y, Xu L, et al. (2015) Anti-Mycobacterium tuberculosis active metabolites from an endophytic Streptomyces sp. YIM65484. Rec Nat Prod 9: 196-200.

9. Dong J, Cai L, Xiong J, Chen X, Wang W, et al. (2015) Improving the antioxidant and antibacterial activities of fermented Bletilla striata with Fusarium avenaceum and Fusarium oxysporum. Process Biochem 50: 8-13. 